\title{
Characterization of microbial activity in the surface layers of a coastal sub-tropical sediment
}

\author{
James A. Novitsky ${ }^{1}$ \& David M. Karl ${ }^{2}$ \\ ${ }^{1}$ Department of Biology, Dalhousie University, Halifax, Nova Scotia B3H 4J1, Canada \\ ${ }^{2}$ Department of Oceanography, University of Hawaii, Honolulu, Hawaii 96822, USA
}

\begin{abstract}
Microbial biomass, metabolic activity, and nucleic acid synthesis were measured throughout a vertical profile of a coastal sub-tropical marine sediment. Heterotrophic activity, as measured by the uptake and respiration of ${ }^{14} \mathrm{C}$-glutamic acid, varied between individual sediment cores but generally was constant with depth for a given sample. Biomass (as determined by ATP concentrations) and DNA and RNA synthesis rates (as measured by the incorporation of ${ }^{3} \mathrm{H}$-adenine) were consistently higher at the sediment-water interface and decreased with depth. Consequently, the biomass(ATP)-specific rate of heterotrophic uptake increased sharply with depth while the biomassspecific rates of RNA and DNA synthesis remained constant. These data indicate the presence of a large microbial biomass associated with the sediment-water interface and a smaller but equally competent population deeper within the sediment. Furthermore, cell division (DNA synthesis) does not appear to be directly correlated with heterotrophic activity; however, data from both methods yield important and independent information concerning the metabolism of the microbial population as a whole.
\end{abstract}

\section{INTRODUCTION}

Although recognized as a important component of the marine ecosystem, the microbiology of marine sediments has, until recently, been somewhat overlooked. With the advent of new techniques and increasing interest in the sediments, data are accumulating that indicate large and active sediment microbial populations (Anderson et al. 1981, Chocair \& Albright 1981, Hanson \& Gardner 1978, Meyer-Reil et al. 1980, Novitsky \& Kepkay 1981). The research to date has focused on the measurement of specific aspects of microbial ecology such as biomass determination (Cammen 1982, Koop \& Griffiths 1982), heterotrophic activity (Griffiths et al. 1978, Meyer-Reil 1978, MeyerReil et al. 1978), nitrogen metabolism (Koike \& Hattori 1978a, b, Oren \& Blackburn 1979, Sørensen 1978), sediment chemistry (Meyer-Reil et al. 1980, Novitsky et al. 1980, Hargrave \& Phillips 1981), and microbial growth and production (Craven \& Karl 1984, Moriarty \& Pollard 1981). With the exception of one study (Fallon et al. 1983), no attempts have been made to coordinate the major lines of research. The purpose of our investigation was to examine the microbial ecology of a coastal sediment using 2 independent techniques, concurrently, to specifically test our working hypothesis that microbial metabolic activity and growth are coupled in marine sediments.

The techniques used were the heterotrophic uptake technique used in sediments by Novitsky (1983a) and Novitsky \& Kepkay (1981), which is a derivation of the method of Griffiths et al. (1977), and the ${ }^{3} \mathrm{H}$-adenine technique for measuring rates of DNA and RNA synthesis used in sediments by Craven \& Karl (1984) which is a derivation of the basic method of Karl (1981). To our knowledge, these techniques have never been used concurrently in a study of a marine sediment or water column. It was hoped that the combined techniques would yield more information concerning the microbiology of the sediment then the individual techniques employed separately and that a direct comparison of the techniques would be possible.

\section{MATERIALS AND METHODS}

Sampling site and sample collection. All sediment used in this study was collected from Kahana Bay on the north side of the island of Oahu, Hawaii (Fig. 1). The sediment is characterized as a fine-grained silt 


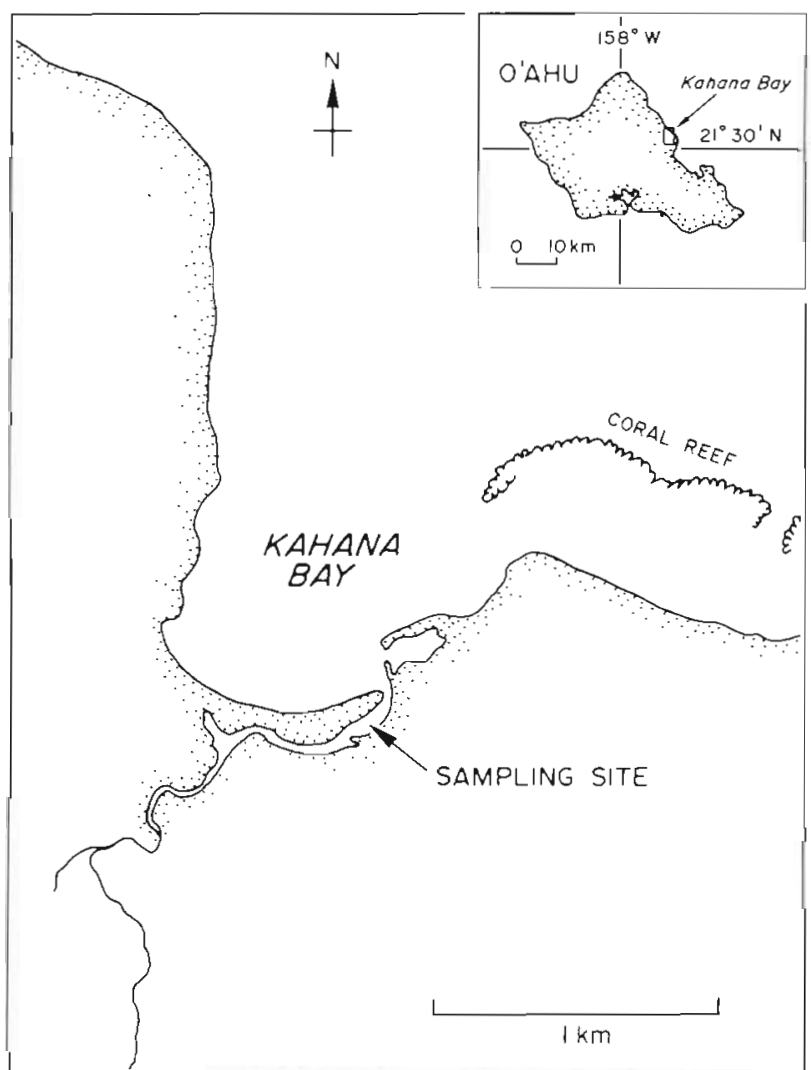

Fig. I Map indicating the sampling site, Kahana Bay, on the north site of the island of Oahu, Hawaii

with an average organic content of $10 \%$ (Coulbourn 1971). Samples were collected in plastic core tubes, by hand, as previously described (Novitsky 1983a, b). Depending upon the tide, overlying water at the sampling site varied from 0.5 to $1.0 \mathrm{~m}$. Sampling was conducted on the following dates: 18 Oct 1983; $13 \mathrm{Dec}$ 1983; 10 Jan 1984; 7 Feb 1984. Cores were taken approximately 10 to $15 \mathrm{~m}$ from the shoreline covering an area of approximately $100 \mathrm{~m}^{2}$. Once collected, the sediment samples were transported immediately to the laboratory. Water samples were also taken by hand in clean polypropylene or polycarbonate bottles.

Subsampling procedures. The sediment-water interface layer was removed by aspiration as previously described (Novitsky 1983a). Once the interface was removed, the overlying water was carefully decanted and the sediment extruded vertically by forcing a rubber plug through the bottom of the core tube. When 1 $\mathrm{cm}$ of sediment was extruded it was removed with a spatula and the process was repeated until five $1 \mathrm{~cm}$ horizons had been collected. Unsieved sediment was then used directly (sediment plug) or suspended in filter-sterilized bottom water to yield a sediment slurry containing approximately $2.5 \mathrm{mg}$ dry weight of sediment $\mathrm{ml}^{-1}$ of slurry.
ATP determinations. Sediment plugs $\left(2 \mathrm{~cm}^{3}\right)$ were placed directly into $10 \mathrm{ml}$ of cold, $1.47 \mathrm{M} \mathrm{H}_{3} \mathrm{PO}_{4}$ and were vigorously mixed. After an extraction period of 10 $\mathrm{min}$, the samples were centrifuged and $0.1 \mathrm{ml}$ of the supernatant was diluted into $4.9 \mathrm{ml}$ of phosphate buffer $(60 \mathrm{mM}, \mathrm{pH} 7.4)$ and assayed for ATP according to the methods of Karl \& Craven (1980). For interface samples, $1 \mathrm{ml}$ of the slurry was pipetted directly into $5 \mathrm{ml}$ of boiling $60 \mathrm{mM}$ phosphate buffer, $1 / 2 \mathrm{ml}$ at a time, and extracted at $100^{\circ} \mathrm{C}$ for $5 \mathrm{~min}$. Internal ATP standards were used to correct for real and apparent losses of extractable ATP.

Heterotrophic activity measurements. Relative heterotrophic activity was measured by a modification of the single concentration of substrate method described by Griffiths et al. (1977), using U- ${ }^{14} \mathrm{C}$ glutamic acid (specific activity, $294 \mathrm{mCi} \mathrm{mmol}^{-1}$ ). Ten $\mathrm{ml}$ portions of seawater or sediment slurry were placed into $50 \mathrm{ml}$ serum bottles, labeled substrate $(0.1 \mu \mathrm{Ci})$ was added to each and the bottles were sealed with serum stoppers. Incubations were carried out at $23 \pm$ $1{ }^{\circ} \mathrm{C}$ for 10 min (sediment and interface samples) or $2 \mathrm{~h}$ (water samples) before terminating the reaction by injecting $1 \mathrm{ml}$ of $0.5 \mathrm{~N} \mathrm{HCl} .{ }^{14} \mathrm{CO}_{2}$ was collected on filter paper wicks saturated with $\beta$-phenethylamine. After collection of the $\mathrm{CO}_{2}$, the bottles were placed on ice and $10 \mathrm{ml}$ of cold $2 \mathrm{~N} \mathrm{HCl}$ was added to each bottle to precipitate the macromolecules. After $1 \mathrm{~h}$, the macromolecules were collected on membrane filters $(0.45 \mu \mathrm{m}$ pore size, type HA, Millipore Corp.). The filters were dried overnight at $60^{\circ} \mathrm{C}$ and then oxidized in an Oxymat model JA101 sample oxidizer in preparation for liquid scintillation counting

DNA and RNA synthesis measurements. At the same time as the heterotrophic activity measurements were conducted, DNA and RNA synthesis rates were determined using $30 \mathrm{ml}$ portions of the sediment slurries. [2]- ${ }^{3} \mathrm{H}$-adenine (specific activity, $15.5 \mathrm{Ci} \mathrm{mmol}^{-1}$ ) was added to the slurries to a final concentration of $0.3 \mu \mathrm{Ci}$ $\mathrm{ml}^{-1}$ and the samples were incubated at $23 \pm 1^{\circ} \mathrm{C}$ on a slow-speed gyrotory shaker table (20 to $25 \mathrm{rpm}$ ). At various times duplicate $1 \mathrm{ml}$ subsamples were filtered onto Whatman GF/F glass fiber filters which were then immediately washed with $10 \mathrm{ml}$ of cold $1 \mathrm{~N} \mathrm{HCl}$. The filters were then placed into tubes and frozen. Radioactive RNA and DNA were separated and measured by the method of Karl (1981) as adapted for sediment samples by Craven \& Karl (1984). The specific radioactivity of the ATP pool was measured at each time point by injecting a $0.5 \mathrm{ml}$ portion of the sediment slurry into $5 \mathrm{ml}$ of boiling phosphate buffer $(60 \mathrm{mM}, \mathrm{pH}$ 7.4) followed by sample concentration and purification as described previously (Craven \& Karl 1984). Rates of RNA and DNA synthesis were calculated from the average rate of isotope incorporation $\left(\mathrm{nCi} \mathrm{ml} l^{-1} \mathrm{~min}^{-1}\right.$ ) 
during an incubation period of $1 \mathrm{~h}$ divided by the integral of the ATP pool specific activity (Winn \& Karl 1984). The production of ${ }^{3} \mathrm{H}_{2} \mathrm{O}$ was also monitored in each time course experiment (Karl 1981).

Abiotic substrate binding measurements. Sediment slurries were placed into $50 \mathrm{ml}$ serum bottles, the bottles were capped with rubber stoppers, and then lowered into a Mark IV ${ }^{60} \mathrm{Co}$ gamma irradiator. A dose of $2.5 \mathrm{Mrad}$ (approximately $10 \mathrm{~h}$ exposure) was found to be sufficient for complete sterilization. Sterile, radioactive substrate was aseptically added to the sediment slurries and abiotic adsorption was monitored by filtration of a portion of the sediment slurry at various times. The filters were dried and then oxidized (as described above) in preparation for liquid scintillation counting.

\section{RESULTS}

The sampling site was a shallow sub-tropical bay characterized by a maximum water depth of approximately 2 m overlying a mud bottom. A complete chemical and sedimentary description has been published elsewhere (Coulbourn 1971). Although the bay is fed by Kahana Stream, appreciable freshwater input occurs infrequently, only during periods of heavy rainfall. The sediment of the bay receives a rather large quantity of organic matter in the form of leaf litter from the surrounding vegetation and the top layers of sediment are regularly mixed by infaunal bioturbation, wind-driven turbulence, and human activity such as the setting of crab traps. The top $5 \mathrm{~cm}$ of sediment used in these experiments was aerobic and appeared uniform in texture and color: fairly dense-packed darkbrown sediment. Occasionally some black sediment was intermixed in the upper layers but usually the predominantly black sediment was found below $5 \mathrm{~cm}$. The odor of $\mathrm{H}_{2} \mathrm{~S}$ was noticeable in the deeper sediments.

The ATP content of the sediment as determined by triplicate determinations from 5 separate cores is shown in Fig. 2. The interface consistently contained more than twice the ATP found in the surface 10 to 1 $\mathrm{cm})$ sediment. The ATP content also generally decreased with depth but detectable amounts were always present, even in the deepest sediments examined. The variability of ATP content between cores was not great; however, an occasional core would be found to contain an abnormally large amount of ATP in the interface and surface horizons (Fig. 2). The ATP concentration in the overlying seawater was $25.2 \mathrm{pg} \mathrm{ATP} \mathrm{ml}^{-1}$ or over 2 orders of magnitude less than the interface habitat.

The relative heterotrophic activity of the microbial populations in the bottom water and sediment is shown

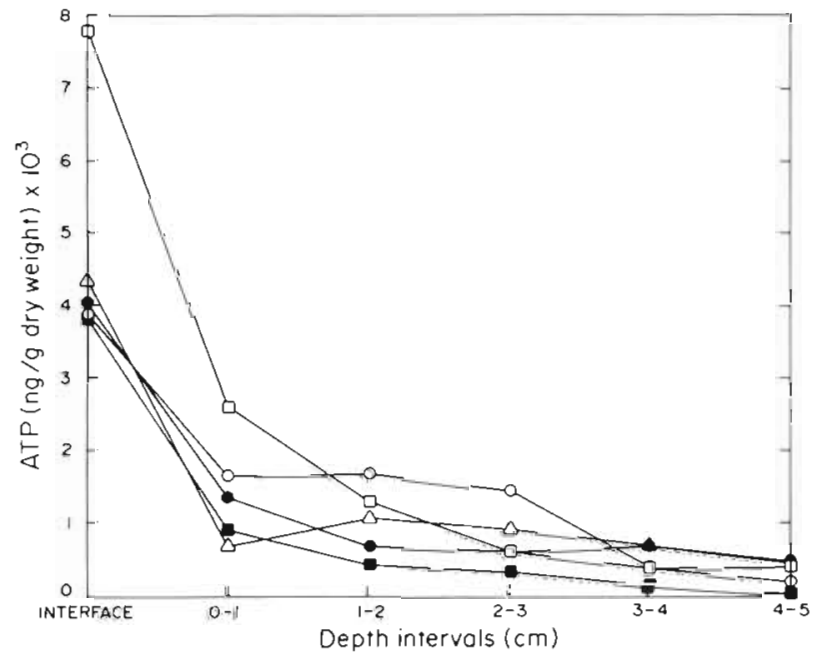

Fig. 2. Variability of ATP measurements of sediment horizons for 5 cores collected on the same day ( 7 Feb 1984) from an area of approximately $100 \mathrm{~m}^{2}$. Each curve represents data from a separate core. Each point represents the mean of 3 determinations

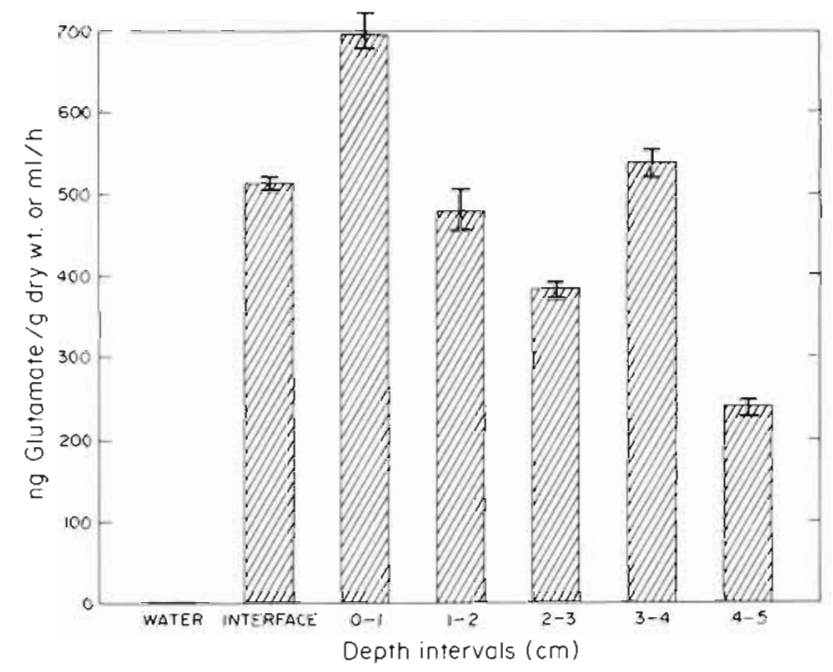

Fig. 3. Relative heterotrophic uptake of bottom water and the top $5 \mathrm{~cm}$ of sediment from Kahana Bay collected on 10 Jan 1984. Main bars represent mean of 3 determinations; range indicated by smaller bars

in Fig. 3. Unlike the ATP profiles, the interface values were not consistently higher than the values for the surface sediment (Fig. 4). Overall, the heterotrophic activity appears to be independent of depth, at least to a depth of $4 \mathrm{~cm}$. The heterotrophic uptake activity of the bottom water was only $580 \mathrm{pg}$ glutamate $\mathrm{ml}^{-1} \mathrm{~h}^{-1}$, almost 3 orders of magnitude lower than the sediment activity. The percentage of substrate taken up that was respired was also relatively constant with depth averaging $20.3 \%$ (range 18.7 to $24.5 \%$ ). By comparison, the percent respired in the bottom water was $60.9 \%$. 


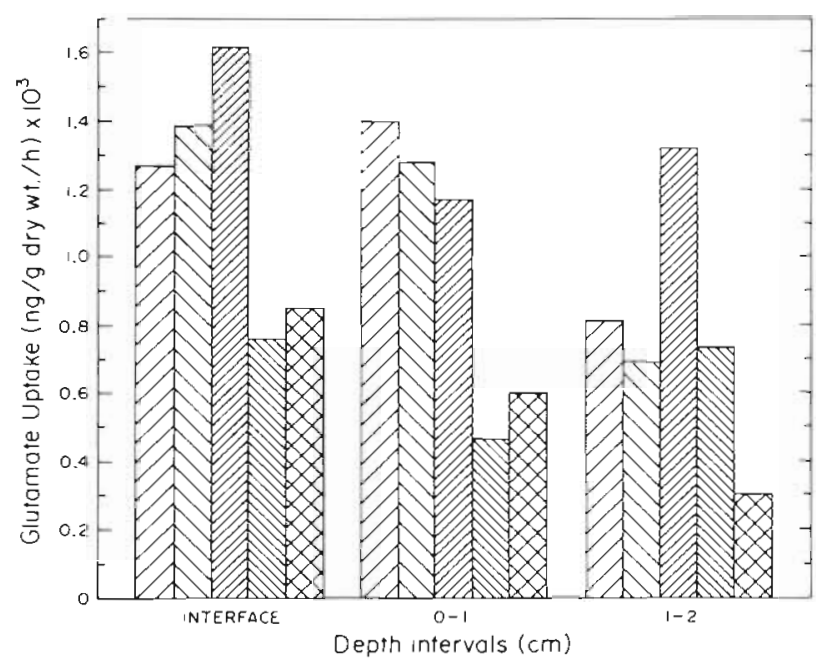

Fig. 4. Variability in heterotrophic activity of the interface and top $2 \mathrm{~cm}$ of sediment from Kahana Bay. All 5 cores were collected on the same day ( 7 Feb 1984) from an area of approximately $100 \mathrm{~m}^{2}$. Each bar represents the mean of 3 determinations; the 5 shading patterns indicate the separate cores

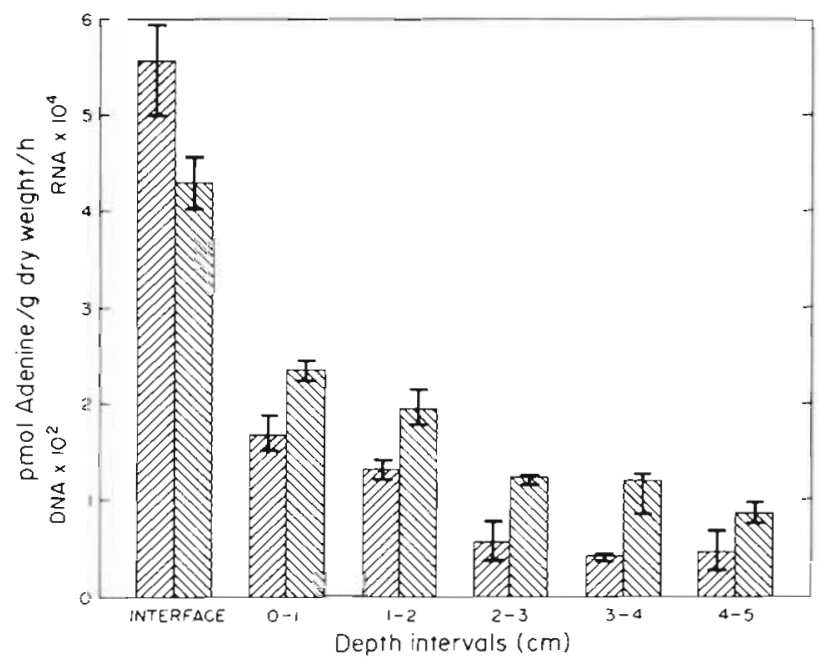

Fig. 5. DNA and RNA synthesis rates through a vertical profile of sediment collected on 10 Jan 1984. Left bar, DNA synthesis; right bar, RNA synthesis. Main bars represent mean of 5 determinations; range indicated by smaller bars

Unlike the heterotrophic activity, the rates of DNA and RNA synthesis dropped off sharply with depth (Fig. 5). In addition, the rate of DNA synthesis in the interface was consistently 2 to 3 times higher than that measured for the surface sediment (data from 3 other sampling dates not shown). Although the pattern of DNA and RNA synthesis rates with depth were similar, the rate of RNA synthesis was always approximately 100 times that of the DNA synthesis.

The biomass-specific rates of heterotrophic uptake and DNA and RNA synthesis are shown in Fig. 6. Both

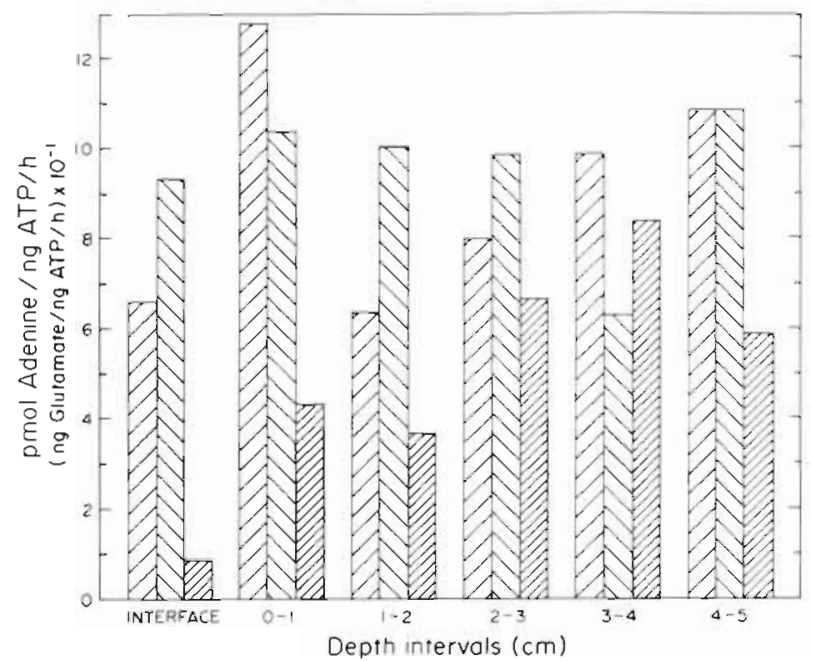

Fig. 6. Biomass-specific rates of heterotrophic uptake and DNA and RNA synthesis through a vertical profile of sediment. Left bar, RNA synthesis; center bar, DNA synthesis; right bar, heterotrophic uptake. Data used to calculate the rates were collected on $10 \mathrm{Jan} 1984$. Uptake and ATP data are means of 3 determinations each; synthesis data are means of 5 determinations

the biomass-specific DNA and RNA synthesis rates remain constant with depth. The biomass-specific heterotrophic activity, however, was relatively low for the interface sample and generally increased with depth.

The results using gamma-irradiated sediment indicated that both substrates were bound abiotically to the sediment particles (data not shown). The particles bound approximately $5 \%$ of the available substrate. The binding was reversible and appeared to reach equilibrium almost instantly. When unbound substrate was removed, bound substrate desorbed to re-establish equilibrium. Glutamic acid binding was independent of $\mathrm{pH}$ whereas adenine binding was greatly decreased at $\mathrm{pH}$ values above 10 .

\section{DISCUSSION}

Due to the spatial heterogeneity of the sediment in our study area and the temporal perturbations it receives, data on variability was a principal concern. However, experiments carried out on 4 different sampling dates produced variation in the data that did not exceed the variation observed when 5 cores were taken on the same day. A more serious problem posed by this sediment was the abiotic adsorption of adenine. Studies conducted with gamma-irradiated sediment showed that under acidic conditions, adenine was adsorbed, while under basic conditions, adenine was released. This posed a serious problem during the base 
hydrolysis of RNA resulting in a large amount of unreacted ${ }^{3} \mathrm{H}$-adenine contaminating the RNA hydrolysis products. Attempts to eliminate the adsorbed adenine failed and consequently RNA synthesis rates were obtained from the slope of ${ }^{3} \mathrm{H}$-RNA accumulation versus time, thus necessitating time course rather than single endpoint measurements. This method assumes that the abiotic adsorption is constant with time. Studies with adenine showed that this is not strictly the case; however, adsorption was rapid (on the order of seconds) and subsequent increases were slight. ${ }^{3} \mathrm{H}$ DNA measurements, on the other hand, were unaffected by the adsorbed adenine and hence no corrective measures were required. Consequently, we have more confidence in the DNA rate determinations.

Overall, the results from the abiotic binding experiments were disappointing in that they did not reveal a large amount of information on the kinetics of substrate adsorption/desorption. Since only a small portion of the available substrate is bound and since the binding is reversible, it does not appear that sediment substrate binding has any effect on these types of studies. Additional experiments providing only bound substrate to the microbial population revealed that the abiotic desorption rate was always greater than the biological utilization rate. It was therefore impossible to conclusively determine any role of abiotic substrate binding in these studies.

Sediment slurries were used in this study and it was determined that the conversion from volume of slurry to gram dry weight of sediment was valid for slurries

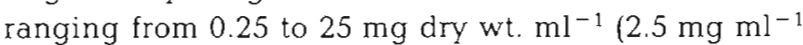
was routinely used). By using slurries rather than intact sediment columns or plugs, uniform mixing of the added labeled substrate was assured. It has been our experience using dense, compact sediment such as Kahana Bay mud that substrate distribution is not uniform even after 'apparent thorough' mixing. The suspension of sediment did not seem to inhibit or enhance microbial activity as judged by the linear and proportional response of glutamate uptake and adenine incorporation over time for various concentrations of sediment slurries. In addition, experiments extended for a period of up to $18 \mathrm{~h}$ continued to exhibit linear uptake provided the labeled substrate was not exhausted. If resuspension enhanced the microbial activity of these sediments, it would be expected that less dense suspensions would have greater activity and/or increasing rates of activity. Such results were never observed. A second advantage with the use of fairly dilute slurries was that the heterotrophic uptake data can be directly compared without reservations regarding differences in the ambient glutamate concentration as the concentration of glutamate from the interstitial water was negligible relative to the con- tribution from the seawater diluent. Attempts to measure the concentration of glutamic acid and other amino acids in the pore or bottom water were unsuccessful as the concentrations were below the detection limit of the high pressure liquid chromatography techniques used $\left(0.5 \mathrm{nmol} 1^{-1}\right)$. All sediment samples, however, were suspended in the same botton water and the actual substrate concentration $\left({ }^{12} \mathrm{C}+{ }^{14} \mathrm{C}\right)$ therefore, was virtually the same in all cases. The relative heterotrophic activity therefore, should be accurate since the ratio of bottom water to sediment was always approximately 100:1, effectively negating any small differences in the chemistry of the pore waters. The actual uptake rates for glutamic acid may be slightly higher than the relative rates reported here if the small amount of ${ }^{12} \mathrm{C}$-glutamate is taken into account. The small amounts of amino acids (and probably other substrates as well) in the sediment pore waters pose not only an analytical problem but also theoretical problems as well. Are these low substrate concentrations a reflection of low production or high consumption rates? The heterotrophic uptake data presented here indicate a rather high consumption rate; if this is true in situ, the production rates must be at least as high. Since the input of organic matter from detritus and photoautotrophs in this system is limited to the interface and the chemoautotrophs are probably limited in number, a very active heterotrophic population would be expected to account for most of the nutrient cycling activity.

The sediment-water interface in Kahana Bay is microbiologically well defined by a large increase in heterotrophic activity and a decrease in the percentage of the substrate that is respired. These results indicate not only a larger, but also a physiologically distinct, microbial population in the sediment. In these respects, the sediment of Kahana Bay is similar to the sediment of Halifax Harbor (Novitsky 1983a); however, the Halifax Harbor sediment-water interface is characterized by an increased heterotrophic activity compared to the sediment immediately below. The Kahana Bay interface is not more active, in terms of glutamate uptake, than the sediment below, but the interface does contain a larger microbial biomass (Fig. 2) and hence, increased DNA and RNA synthesis (Fig. 5).

In absolute terms, the heterotrophic activity measured for the Kahana Bay sediment is more than 10 times greater than that measured for Halifax Harbor (Novitsky 1983a) using the same methods. The reasons for this include the large difference in temperature $\left(25^{\circ}\right.$ vs $2{ }^{\circ} \mathrm{C}$ for Halifax Harbor) and probably more importantly, the increased amount of organic matter reaching the Kahana sediment surface. The ATP biomass and RNA and DNA synthesis rates are also much 
higher than those measured by Craven \& Karl (1984) for a variety of marine sediments.

To our knowledge, this is the first study directly comparing techniques for measuring heterotrophic activity and nucleic acid synthesis. Our results indicate that there is no obligate correlation between heterotrophic activity and any of the following: ATP biomass, ${ }^{3} \mathrm{H}_{2} \mathrm{O}$ production from ${ }^{3} \mathrm{H}$-adenine, or ${ }^{3} \mathrm{H}$-adenine incorporation into RNA or DNA. This lack of correlation is puzzling. On an a priori basis, one might expect that cell metabolism and growth would be tightly coupled in microbial cells inhabiting natural ecosystems as they are in bacterial cultures. However, this may not be the case. Microbial cells in the environment may exhibit unbalanced growth, i.e. they may be capable of certain types of metabolism without a concomitant increase in biomass. Until this point is resolved, data concerning heterotrophic activity and growth measurements must be interpreted cautiously.

Another possibility for the lack of correlation is that the methods used are not good measurements of heterotrophic activity and/or growth and production rates. Since the nucleotide incorporation method uses a universal substrate, measures specific products, i.e. RNA and DNA, and has been shown to correlate well with chemostat cultures (Winn \& Karl 1984), it can be concluded that it is a reliable measure of growth and biomass production. The heterotrophic uptake method, on the other hand, uses an arbitrary substrate, measures a wide variety of products, and has never been carefully examined with laboratory cultures. Another problem in comparing the 2 methods is the fact that the adenine incorporation method measures DNA and RNA synthesis for both autotrophic and heterotrophic populations whereas the heterotrophic uptake method measures organic carbon uptake, presumed to be an almost exclusive heterotrophic process. Clearly, the 2 methods measure different parameters of total microbial community activity, valid individually and complementary, but not directly comparable without further study,

The results indicate that this sediment is characterized as having a microbial population that is growing at the same per capita rate independent of depth, but due to the large amount of biomass in the interface, the largest amount of cellular biosynthesis occurs within the first few $\mathrm{mm}$ of sediment. The total amount of heterotrophic activity is independent of depth but on a biomass-specific, and presumably a per cell, basis, the greatest apparent activity is deeper in the sediment. It would appear from these data that the factors controlling microbial growth and heterotrophic mineralization are not the same. The nature and number of these factors, however, are still unknown. Another possibility, due to the fact that the ATP biomass technique measures all ATP (from both autotrophic and heterotrophic sources), is that ATP biomass is not a suitable denominator for biomass-specific heterotrophic uptake. It seems likely that at least part of the interface biomass is due to algae. If this biomass could be subtracted from the total, the biomass-specific heterotrophic uptake of the interface would increase. Since we have no a priori reason to rule out either hypothesis, we hesitate to draw any final conclusions concerning the per cell heterotrophic uptake of these sediments. Since adenine is incorporated by both heterotrophic and autotrophic populations, this limitation does not pertain to these data.

Three factors that probably play an important role in the microbial ecology of sediments are the concentration and composition of organic matter present and the presence of bacterial grazers. The fact that the microbial biomass decreases greatly from the interface to the sediment immediately below suggests the presence of a population of microbial grazers. Another study (Novitsky 1983a) also indicated this possibility by noting the large decrease in direct counts of bacteria immediately below the interface. Since no data exist on the extent of microbial grazing in marine sediments, the question of the destruction of microbial biomass remains unanswered.

Acknowledgements. We are grateful to U. Magaard for excellent technical help and Jean Novitsky for field assistance. J. Novitsky thanks D. Karl and the Department of Oceanography, University of Hawaii, for their facilities and cooperation that made this research possible during his sabbatical leave there.

This research was funded by grant OCE82-16673 from the National Science Foundation and grants A-6548 and T-1925 from the National Research Council of Canada.

\section{LITERATURE CITED}

Anderson, J. G., Boonruang, P., Meadows, P. S. (1981). Interrelationships between chlorophylls, carbon, nitrogen and heterotrophic bacteria in an intertidal sediment transect. Mar. Ecol. Prog. Ser 6: 277-283

Cammen, L. M. (1982). Effect of particle size on organic content and microbial abundance within four marine sediments. Mar Ecol. Prog. Ser. 9: 273-280

Chocair, J. A., Albright, L. J. (1981). Heterotrophic activities of bacterioplankton and bacteriobenthos. Can. J. Microbiol. 27 : 259-266

Coulbourn, W T (1971). Sedimentology of Kahana Bay, Oahu, Hawaif. M. S. thesis, Univ. of Hawaii

Craven, D. B., Karl, D. M. (1984). Microbial RNA and DNA synthesis in marine sediments. Mar Biol. 83: 129-139

Fallon, R. D., Newell, S. Y., Hopkinson, C. S. (1983). Bacterial production in marine sediments: will cell-specific measures agree with whole-system metabolism? Mar Ecol. Prog. Ser 11 119-127

Griffiths, R. P., Haysaka, S. S., McNamara, T M., Morita, R. Y (1977). Comparison between two methods of assay- 
ing relative microbial activity in marine environments. Appl. environ. Microbiol. 34: 801-805

Griffiths, R. P., Haysaka, S. S., McNamara, T M., Morita, R. Y (1978). Relative microbial activity and bacterial concentrations in water and sediment samples taken in the Beaufort Sea. Can. J. Microbiol. 24: 1217-1226

Hanson, R. B., Gardner, W. S. (1978). Uptake and metabolism of two amino acids by anaerobic microorganisms in four diverse saltmarsh soils. Mar Biol 46: 101-107

Hargrave, B. T., Phillips, G. A. (1981). Annual in situ carbon dioxide and oxygen flux across a subtidal marine sediment. Estuar coast. Shelf Sci. 12: 725-737

Karl, D. M. (1981). Simultaneous rates of ribonucleic acid and deoxyribonucleic acid syntheses for estimating growth and cell division of aquatic microbial communities. Appl. environ. Microbiol. 42: 802-810

Karl, D. M., Craven, D. B. (1980). Effects of alkaline phosphatase activity on nucleotide measurements in aquatic microbial communities. App. environ. Microbiol. 40: 549-561

Koike, I., Hattori, A. (1978a). Denitrification and ammonia formation in anaerobic coastal sediments. Appl. environ. Microbiol. 35: 278-282

Koike, I., Hattori, A. (1978b). Simultaneous determinations of nitrification and nitrate reduction in coastal sediments by a ${ }^{15} \mathrm{~N}$ dilution technique. Appl. environ. Microbiol. 35: 853-857

Koop, K., Griffiths, C. L. (1982). The relative significance of bacteria, meio- and macrofauna on an exposed sandy beach. Mar. Biol. 66: 295-300

Meyer-Reil, L.-A. (1978). Uptake of glucose by bacteria in the sediment. Mar. Biol. 44: 293-298

Meyer-Reil, L.-A., Dawson, R., Liebezeit, G., Tiedge, H. (1978). Fluctuations and interactions of bacterial activity in sandy beach sediments and overlying waters. Mar. Biol. 48: 161-171

Meyer-Reil, L.-A., Bölter, M., Dawson, R., Liebezeit, G., Szwerinski, H., Wolter, K. (1980). Interrelationships between microbiological and chemical parameters of sandy beach sediments, a summer aspect. Appl. environ Microbiol. 39: 797-802

Moriarty, D. J. W., Pollard, P. C. (1981). DNA synthesis as a measure of bacterial productivity in seagrass sediments. Mar Ecol. Prog. Ser. 5: 151-156

Novitsky, J. A. (1983a). Heterotrophic activity throughout a vertical profile of seawater and sediment in Halifax Harbor, Canada. Appl. environ. Microbiol. 45: 1753-1760

Novitsky, J. A. (1983b). Microbial activity at the sedimentwater interface in Halifax Harbor, Canada. Appl. environ. Microbiol. 45: 1761-1766

Novitsky, J. A., Kepkay, P. E (1981). Patterns of microbial heterotrophy through changing environments in a marine sediment. Mar. Ecol. Prog. Ser. 4: 1-7

Novitsky, J. A., Scott, I. R., Kepkay, P. E. (1980). Effects of iron, sulfur, and microbial activity on aerobic to anaerobic transitions in marine sediments. Geomicrobiol. J. 2: 211-223

Oren, A., Blackburn, T. H. (1979). Estimation of sediment denitrification rates at in situ nitrate concentrations. Appl. environ. Microbiol. 37: 174-176

Sørensen, J. (1978). Capacity for denitrification and reduction of nitrate to ammonia in a coastal marine sediment. Appl. environ. Microbiol. 35: 301-305

Winn, C. D., Karl, D. M. (1984). Laboratory calibrations of the ${ }^{3} \mathrm{H}$-adenine technique for measuring rates of RNA and DNA synthesis in marine microorganisms. Appl. environ. Microbiol. 47: 835-842

This paper was presented by Professor P. J. Wangersky; it was accepted for printing on September 23, 1985 